\title{
Optimization of Nitrification Process by a Bacterial Consortium in the Submerged Biofiltration System with Ceramic Bead Carrier
}

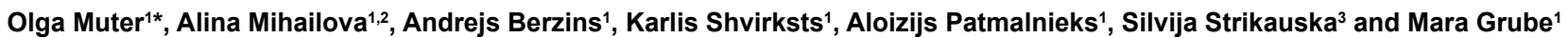

${ }^{1}$ Institute of Microbiology and Biotechnology, University of Latvia, Latvia

${ }^{2}$ University of East Anglia, School of Environmental Sciences, Norwich Research Park, United Kingdom

${ }^{3}$ Latvia University of Agriculture, Latvia

\begin{abstract}
Laboratory-scale solid phase submerged system was developed to study the process of ammonium biodegradation. Ceramic beads were found to be an appropriate carrier material for the attachment of thePNN bacterial consortium (Pseudomonas sp., Nitrosomonas sp., Nitrobacter sp.) exhibiting nitrification/denitrification activity. This consortium was previously isolated from a biological activated sludge process at a fish factory wastewater treatment plant. Three organic amendments - molasses, humic acid extract, and malt extract - were used for the ceramic bead pretreatment. Molasses significantly enhanced $(p<0.05)$ the process of bacteria attachment onto the ceramic carrier and further ammonium removal from the bulk liquid media. The addition of $0.45 \%$ fructose to the column notably enhanced ammonium oxidation, as demonstrated by more rapid formation of nitrites in the medium when compared to the sets without sugars. The results of this study could be incorporated in a larger-scale test of a biofiltration column using wastewater from a fish processing factory.
\end{abstract}

Keywords: Ammonium biotransformation; Enzyme activity; Ceramic beads; Molasses; Nitrification

\section{Introduction}

Biofiltration, an emerging technology using bacteria and fungi [1-5], offers a number of advantages for the treatment of organic and inorganic pollutants in air and water. The packing material used in biofilters is an important factor for establishing high removal efficiency and maintaining good performance over the long term [6]. The characteristics of the filter media have a great impact on the treatment efficiency and, to a great extent, determine construction and operations costs $[7,8]$.

Some of the most frequently used inert packing materials include perlite, porous ceramics, activated carbon, porous lava, polyamide and polypropylene beads, and polyvinyl difluoride cubes has become prevalent [1,9-13]. Although the cost of inert filter beads, in most cases, is higher compared to that of organic counterparts, the former have a range of advantages: chemical and physical inactivity, long lifetime, high performance, more regular shape, uniform air distribution, and reduced number of channeling issues. In addition, inert carriers are also much easier to clean and replace $[1,9,14]$. Porous ceramic beads have also been shown to be an appropriate packing material for biofilters due to their high gas and liquid film mass transfer coefficients [12].

Studies on the metabolic pathways of autotrophic ammoniaoxidizing bacteria, heterotrophic nitrifying bacteria, anaerobic ammonia-oxidizing bacteria, and ammonia-oxidizing archaea under various engineered ecosystems could provide a more efficient performance of waste treatment processes [15]. As reported by Raby et al. [16], ammonium biodegradation in biotrickling filter with polypropylene spheres and ceramic beads showed a similar efficiency as packing materials. Operating conditions, e.g., flow rate, leachate recirculation, nitrogen load rate, etc., greatly affected the biomass production and its ammonium oxidation activity.

In a previous study [17], we tested six inorganic materials including naturally occurring minerals and rocks, and found that ceramic beads showed significantly higher attachment capacity $(\mathrm{p}<0.01)$ for the nitrifying consortium of Pseudomonas sp., Nitrosomonas sp.,
Nitrobacter sp., and Sarcina sp. (PNNS). The use of inorganic carriers, however, had to be accompanied by added nutrients that would support the targeted biological processes, including the growth of microorganisms, the formation of biofilm, and biodegradation. The enhancement of these processes is a key factor to a significant increase in biofiltration efficiency.

In this respect, a search for the optimal surface functionalization is considered to be a fundamental tool for development of novel biotechnologies [18].

Commercially available nutrient amendments with complex compositions that are known to stimulate microbial growth include molasses, humic acid extract, and malt extract. Molasses contains about $50 \%$ sugar in the form of sucrose, glucose, and fructose, and is rich in mineral elements [19]. Humic substances which are multifunctional, amorphous biopolymers, composed of hundreds of organic constituents that include carbohydrates and condensed aromatic rings substituted by carboxylic, phenolic, and methoxyl groups. Humic compounds have been shown to serve as an ideal ligand for bioinorganic applications [20]. Malt extract contains about $70 \%$ carbohydrates, as well as amino acids, $\beta$-glucan, and other components, known to stimulate microbial growth [21].

The main goal of this study was to evaluate the effect of different types of ceramic bead pretreatment (with molasses, humic acid

${ }^{*}$ Corresponding author: Dr. Olga Muter, Senior Researcher, Project Manager, Institute of Microbiology and Biotechnology, University of Latvia, 4 Kronvalda Blvd., Riga, LV-1010, Latvia, Tel: +37167034886; Fax: +37167034885; E-mail: olga.muter@inbox.Iv; olga.mutere@lu.Iv

Received February 18, 2014; Accepted March 22, 2014; Published March 26 2014

Citation: Muter O, Mihailova A, Berzins A, Shvirksts K, Patmalnieks A, et al. (2014) Optimization of Nitrification Process by a Bacterial Consortium in the Submerged Biofiltration System with Ceramic Bead Carrier. J Microb Biochem Technol 6: 148153. doi:10.4172/1948-5948.1000136

Copyright: () 2014 Muter O, et al. This is an open-access article distributed under the terms of the Creative Commons Attribution License, which permits unrestricted use, distribution, and reproduction in any medium, provided the original author and source are credited 
Citation: Muter O, Mihailova A, Berzins A, Shvirksts K, Patmalnieks A, et al. (2014) Optimization of Nitrification Process by a Bacterial Consortium in the Submerged Biofiltration System with Ceramic Bead Carrier. J Microb Biochem Technol 6: 148-153. doi:10.4172/1948-5948.1000136

extract, and malt extract) on the attachment capacity and ammonium biodegradation activity of the PNN bacterial consortium. In addition, the effect of fructose on the process of ammonium biodegradation was tested.

\section{Materials and Methods}

\section{Microorganisms and growth conditions}

The ammonium-degrading bacterial consortium PNN (Pseudomonas sp., Nitrosomonas sp., Nitrobacter sp.) was previously isolated from the biological activated sludge process of a fish processing wastewater treatment plant and tested in nitrification/ denitrification experiments with a two stage biofiltration column [22]. The composition of liquid medium used for PNN cultivation was as follows: $1.0 \mathrm{~g} / \mathrm{L}\left(\mathrm{NH}_{4}\right) 2 \mathrm{SO}_{4} ; 1.0 \mathrm{~g} / \mathrm{L} \mathrm{K}_{2} \mathrm{HPO}_{4} ; 2.0 \mathrm{~g} / \mathrm{L} \mathrm{NaCl}$; and $0.5 \mathrm{~g} / \mathrm{L}$ $\mathrm{MgSO}_{4} \cdot 7 \mathrm{H}_{2} \mathrm{O}(\mathrm{pH}=7.37$; redox potential $=-31.4 \mathrm{mV})$.

\section{Pretreatment of ceramic beads with organic amendments}

Sterile ceramic beads (Maxit, Estonia) were used as a packing material in the experimental biofiltration system. Three different organic solutions - 30\% molasses, $30 \%$ malt extract, and $100 \%$ humic acid extract - were used for the bead pretreatment. The control was pretreated with distilled water. The pretreatment was performed in duplicate in eight $1 \mathrm{~L}$ glass flasks by submerging the ceramic beads in the above solutions for 5 hours. Then the excess liquid was discarded, the beads were dried at $60^{\circ} \mathrm{C}$ for $24 \mathrm{~h}$ and used further as a carrier for the attachment of the PNN consortium.

\section{Bacteria attachment and experiments on ammonium degradation}

Biofiltration experiments were performed in $500 \mathrm{~mL}$ glass flasks packed with $120 \mathrm{~g}$ of dry autoclaved ceramic beads. In order to attach the PNN consortium on the beads, the former was placed in the liquid medium in flasks and incubated over a 7 day period using liquid medium described above, at $22^{\circ} \mathrm{C}$. A mean air flow rate of $0.28 \mathrm{~L} / \mathrm{min}$ was maintained in each flask using air pumps (AC-1500, Resun, China) with $0.45 \mu \mathrm{m}$ filters. After incubation, the non-attached biomass was removed and the ammonium degradation experiments were conducted using two concentrations of $\left(\mathrm{NH}_{4}\right) 2 \mathrm{SO}_{4}$, i.e., $2.5 \mathrm{~g} / \mathrm{L}$ and 7.5 $\mathrm{g} / \mathrm{L}$, corresponding to $0.53 \mathrm{~g} / \mathrm{L}$ and $1.6 \mathrm{~g} / \mathrm{L} \mathrm{N}-\mathrm{NH}_{4}^{+}$, respectively.

\section{Analytical methods}

Auto Kjeldahl Unit K-370 (BÜCHI Labortechnik AG, Germany) was used to determine the content of total nitrogen according to ISO 5983-2:2005. Total carbon was measured using an automatic C/S ELTRA analyzer (ELTRA GmbH, Germany). The concentration of $\mathrm{N}^{-\mathrm{NH}_{4}+}$ was determined colorimetricaly with Nessler's reagent. Redox potential and $\mathrm{pH}$ were measured with a Hanna $\mathrm{pH} 213 \mathrm{pH}-$ meter (Hanna Instruments, USA). Fructose (Penta, Czech Republic) concentration was measured using Waters 600E HPLC system (Waters Corporation, USA). The following setup was used for the analysis: Econosphere Amino Column $250 \times 4.6 \mathrm{~mm}$ with a diameter of $5 \mu \mathrm{m}$ and a flow rate of $1.3 \mathrm{~mL} / \mathrm{min}$ and a mobile phase acetonitrile:water ratio of 70:30. For calibration, carbohydrate standards for glucose, fructose, maltose, and sucrose from Sigma Aldrich were used.

To determine fluorescein diacetate (FDA; Fluka, Switzerland) activity, FDA hydrolysis was measured after $24 \mathrm{~h}$ of incubation at $+37^{\circ} \mathrm{C}$ [23]. Fourier transform infrared (FT-IR) absorption spectra were registered on a microplate reader HTS-XT, Vertex 70 (Bruker
Optics, Germany) over the range $4000-400 \mathrm{~cm}^{-1}$ with a resolution of $4 \mathrm{~cm}^{-1}$. The data were processed using OPUS 6.5 software, correcting the baseline by the rubber band method. Quantitative analysis of carbohydrates, nucleic acids, proteins, and lipids in the biomass was performed as in Grube et al. [24]. Prior to analysis biomass was detached from the ceramic beads by sonication in sterile distilled water for $10 \mathrm{~min}$ followed by incubation for $20 \mathrm{~min}$ on a rotary shaker (140 rpm).

Structural analysis of ceramic beads and bacterial biomass was performed using scanning electron microscopy (SEM). Samples were fixed in glutaraldehyde solution (5\% final concentration in $0.1 \mathrm{M}$ phosphate buffer, $\mathrm{pH}$ 7.2) for $20 \mathrm{~h}$. Ceramic beads with immobilized cells were rinsed in distilled water and incubated in a $2 \% \mathrm{KCl}$ solution for $24 \mathrm{~h}$. Then prepared material was dehydrated in an increasing range of acetone concentrations (40,60, 80, 90, and 100\% $10 \mathrm{~min}$ each), and mounted on metal discs. Dried samples were then coated with gold in an Eiko IB-3 ion coater (Eiko Engineering, Japan) and analyzed using the scanning electron microscope Hitachi S-4800 (Hitachi, Japan) at an acceleration voltage of $3.0 \mathrm{kV}$.

\section{Results and Discussion}

\section{Ceramic bead pretreatment}

After the 7-day incubation of PNN consortium in the presence of ceramic beads, the bead surface was visualized using SEM (Figure 1). The pore structure of untreated ceramic beads and the surface of beads pretreated with molasses are shown in Figure 1A and Figure 1B, respectively. PNN incubation resulted in the formation of bacterial biofilm on the bead surface (Figures $1 B$ and 1C).

The enzyme, i.e., FDA hydrolysis activity of PNN consortium was found to be the highest on the beads pretreated with molasses $(\mathrm{p}<0.05)$ (Figure 2). Our previous study [17] demonstrated that molasses had a stimulating effect on the growth of the non-attached consortium in a liquid medium as well as the first phase of the nitrification process.

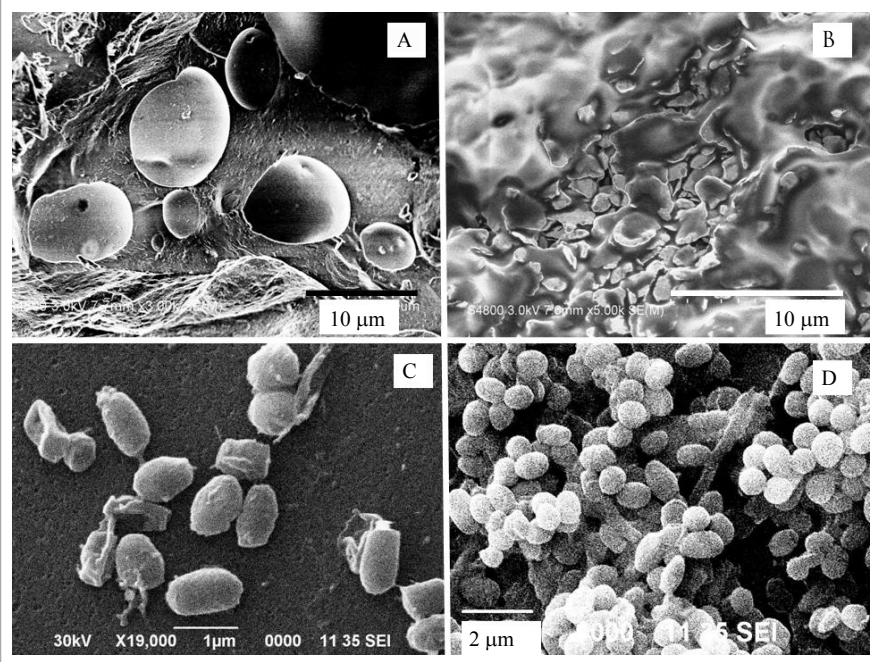

Figure 1: Scanning electron micrographs of the surface of ceramic beads. A beads without treatment; $B$ - beads pretreated with molasses (by submerging the ceramic beads in $30 \%$ molasses during 5 hours, then discarding the excess liquid and drying at $60^{\circ} \mathrm{C}$ for $24 \mathrm{~h}$ ). C, D - the cells of PNN consortium attached on the bead surface (inoculum of PNN consortium was incubated over a 7 day period in medium in the presence of ceramic beads at $22^{\circ} \mathrm{C}$, at air flow rate of $0.28 \mathrm{~L} / \mathrm{min}$ ). 


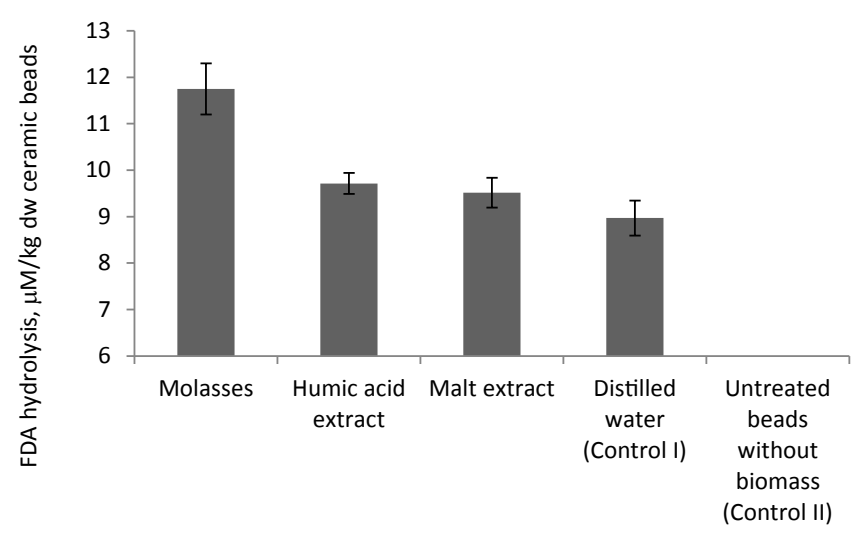

Figure 2: FDA hydrolysis activity of PNN consortium cells attached on the ceramic beads previously treated with different organic amendments or distilled water (Control I). Control II - untreated beads without attached biomass. FDA hydrolysis activity was measured after $24 \mathrm{~h}$ of incubation at $+37^{\circ} \mathrm{C}$. Beads treatment was performed as indicated in Materials and Methods. Error bars represent the standard deviation.

No significant difference ( $\mathrm{p}>0.05)$ in the FDA hydrolysis activity of the attached biomass was observed among the treatments with humic acid extract, malt extract, and distilled water (Figure 2).

The study by Akker et al. [25] evaluated the abundance of ammoniaoxidizing bacteria (Nitrosomonas oligotropha-cluster) in a molassesfed fixed-film activated sludge. It was shown that an excess of molasses could decrease the concentration of ammonium-oxidizing bacteria present in the reactor [25]. In turn, other source of organic carbon, i.e., urea, was shown to stimulate the growth of ammonia-oxidizing communities and the process of nitrification as a whole [26].

In our experiments, Pseudomonas spp. could dominate in the PNN consortium when cultivated with molasses. Further studies are necessary to clarify the shift in the consortium community with the addition of organic carbon.

Concentrations of the total nitrogen, carbon and sulfur in the crushed ceramic beads with attached PNN consortium were determined. No considerable changes in the concentrations of $\mathrm{N}$ and $\mathrm{S}$ were detected in the sets with ceramic beads and attached biomass, among the treatments with organic amendments and distilled water. Total carbon concentration in the beads pretreated with humic acid extract was the highest among the treatments tested (Figure $3 \mathrm{~A}$ ). Untreated ceramic beads without biomass contained considerably lower concentrations of $\mathrm{C}$ and $\mathrm{S}$, as compared to the sets with biomass. Nitrogen was not detected in the set with untreated beads (Figure 3A).

Testing the biomass chemical composition, previously detached from ceramic beads, showed that the concentration of carbon in the biomass was similar for all tested samples (256-292 mg/g dw) (Figure 3B). The total nitrogen concentration was the lowest in the biomass detached from the beads pretreated with water (Figure 3B).

Differences in the chemical composition of the bead surface and the attached biomass can be explained by the individual properties of organic amendments used in this study. Concentrations of the total $\mathrm{N}$, $\mathrm{C}$, and $\mathrm{S}$ in molasses, humic acid extract, and malt extract are presented in Table 1.

FT-IR spectroscopy was used to study the macromolecular composition of microbial biomass that was attached on the ceramic beads with different types of pretreatment. The concentration of carbohydrates, nucleic acids, proteins, and lipids in the PNN biomass is shown in Figure 4. The concentration of carbohydrates in the biomasses pretreated with molasses or malt extract was higher than that in biomass pretreated with humic acid extract or water. On the other hand, biomass attached on the beads pretreated with molasses or malt extract had lower protein concentration than that pretreated with humic acid or water. Conversely, the highest protein concentration $(69.2 \% \mathrm{dw})$ was observed in the PNN biomass grown on ceramic beads that were pretreated with humic acid extract. Amount of nucleic acids varied in the range from $8.63 \%$ (pretreatment with humic acid extract) to $16.77 \%$ (pretreatment with malt extract). The highest concentration of lipids in biomass, i.e., $10.1 \%$, was detected in the set without pretreatment with organic amendments (Figure 4).

Pretreatment of PNN biomass with molasses and humic acid extract resulted in the most pronounced changes including the highest enzymatic activity and the highest protein concentration of the attached biomass (Figures 2 and 4). In this respect, more detailed

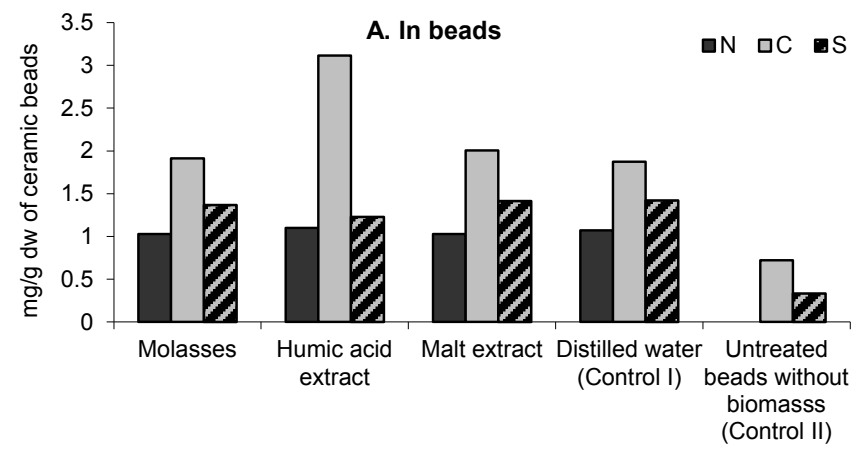

B. In biomass

$\square \mathrm{N} \quad \mathrm{C} \quad \mathrm{S}$

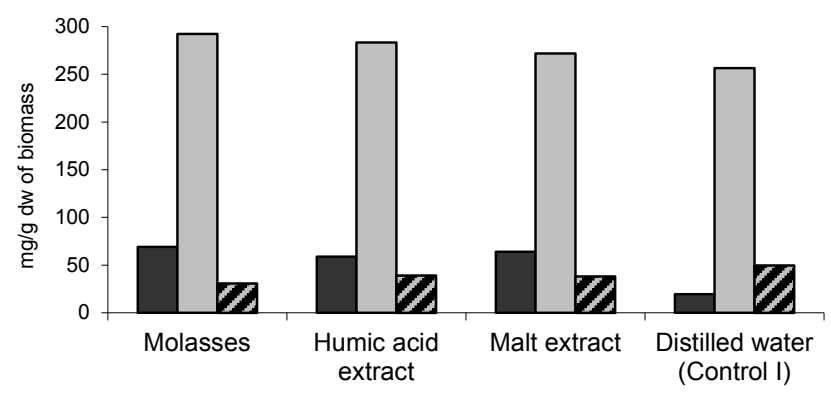

Figure 3: Total nitrogen, carbon, and sulfur concentrations in the crushed ceramic beads with attached PNN consortium (A) and in the biomass of PNN consortium detached from the surface $(B)$. Beads treatment was performed as indicated in Materials and Methods. Control I - treatment of ceramic beads in distilled water; Control II - untreated beads without attached biomass.

\begin{tabular}{|l|l|l|l|l|}
\hline Amendment & $\begin{array}{l}\text { Total } \mathbf{~}(\mathbf{m g} \\
\left.\mathbf{g}^{-1} \mathbf{d w}\right)\end{array}$ & $\begin{array}{l}\text { Total C } \mathbf{( m g ~ g} \\
\mathbf{d w})\end{array}$ & $\begin{array}{l}\mathbf{S}\left(\mathbf{m g ~ g}^{-1}\right. \\
\mathbf{d w})\end{array}$ & $\mathbf{D W}^{\star} \mathbf{( \% )}$ \\
\hline Molasses, 30\% & 11.9 & 278.5 & 1.5 & 22.7 \\
\hline Humic acid extract, 100\% & 11.6 & 417.1 & 6.0 & 3.5 \\
\hline Malt extract, 30\% & 7.9 & 389.2 & 0.9 & 25.4 \\
\hline
\end{tabular}

* - dry weight

Table 1: Total nitrogen, carbon and sulphur concentrations in amendments used for pre-treatment of ceramic beads. 
Citation: Muter O, Mihailova A, Berzins A, Shvirksts K, Patmalnieks A, et al. (2014) Optimization of Nitrification Process by a Bacterial Consortium in the Submerged Biofiltration System with Ceramic Bead Carrier. J Microb Biochem Technol 6: 148-153. doi:10.4172/1948-5948.1000136

attention was focused on the FT-IR spectra profiles of the samples under these treatments (Figure 5). The spectra of both supernatants were qualitatively similar. Changes of the profiles and absorption band intensities at $1580 \mathrm{~cm}^{-1}, 1405 \mathrm{~cm}^{-1}$, and $900-1100 \mathrm{~cm}^{-1}$ indicated the presence of unconverted carbohydrates from the molasses medium and some components of humic acid extract, as well as, possibly, some extracellular substances produced by the PNN consortium. FT-IR spectrum of biomass showed the overall macromolecular composition of cells that allowed particular components to be identified. The most intensive absorption bands were assigned to carbohydrates (900$1100 \mathrm{~cm}^{-1}$ primarily dominated by a sequence of bands due to $\mathrm{C}-\mathrm{O}$, C-O-C and C-O-P stretching vibrations), proteins $\left(1500-1700 \mathrm{~cm}^{-1}\right.$, with maximums of Amid I and Amid II, N-H and $\mathrm{C}=\mathrm{O}$ vibrations, respectively), and lipids (2800-3000 $\mathrm{cm}^{-1}$ dominated by the absorption modes of $\mathrm{CH}_{2}$ and $\mathrm{CH}_{3}$ groups of fatty acids and aliphatic chains). The shoulder at $1712 \mathrm{~cm}^{-1}$ was assigned to $\mathrm{C}=\mathrm{O}$ stretching of ester and/or carbonyl groups, carbonic acid.

The spectrum of Pseudomonas sp. is a typical biosample spectrum where the main absorption bands are assigned to specific functional groups of carbohydrates, proteins and fatty acids [24,27]. Both nitrogen-fixing bacteria Nitrosomonas sp., and Nitrobacter sp. were grown on the same medium, yet the spectra were different. The strong absorption band with maximum at $1737 \mathrm{~cm}^{-1}$ (ester carbonyl stretch) and band at $1450 \mathrm{~cm}^{-1}$ (methyl $\mathrm{CH} 3$ deformation) in the spectrum of Nitrosomonas sp. indicate the accumulated a storage bio-polymer poly - $\beta$-hydroxybutyric acid (PHB) [28], while Nitrobacter sp. did not accumulate $\mathrm{PHB}$.

\section{Ammonium biotransformation in the submerged biofilter}

The rate of ammonium degradation by microorganisms can be influenced by many factors such as the initial ammonium concentration, additional growth factors, and the physiological state of the biomass. We performed experiments to determine how the initial ammonium concentration and the addition of fructose affected the degradation of ammonium in the model system.

In the media without fructose, ammonium degradation by the attached biomass was significantly higher $(p<0.05)$ for the beads pretreated with molasses. The stimulating effect of pretreatment with molasses was more pronounced at a lower initial concentration of ammonium sulphate, i.e., $2.5 \mathrm{~g} / \mathrm{L}$ (Figure 6). As previously documented [29], the activity of ammonium-oxidizing bacteria, in particular Nitrosomonas spp., varies with ammonium concentrations.

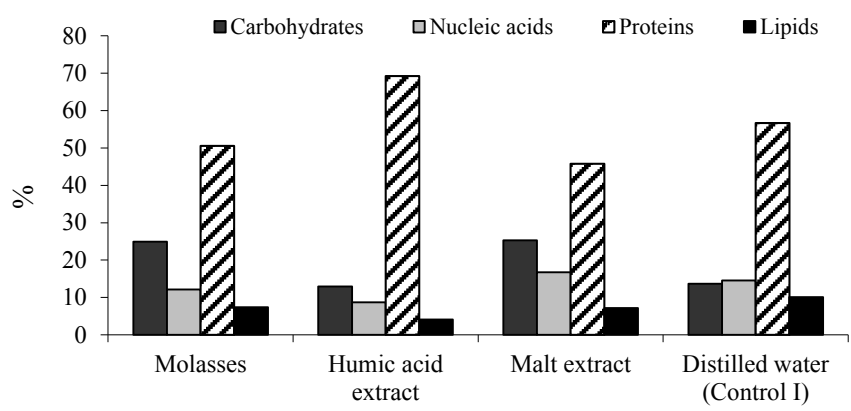

Figure 4: The concentration (\% of dry weight) of the principal cell components in the biomass of PNN consortium attached on the ceramic beads pretreated with different organic amendments or distilled water. Beads treatment was performed as indicated in Materials and Methods.
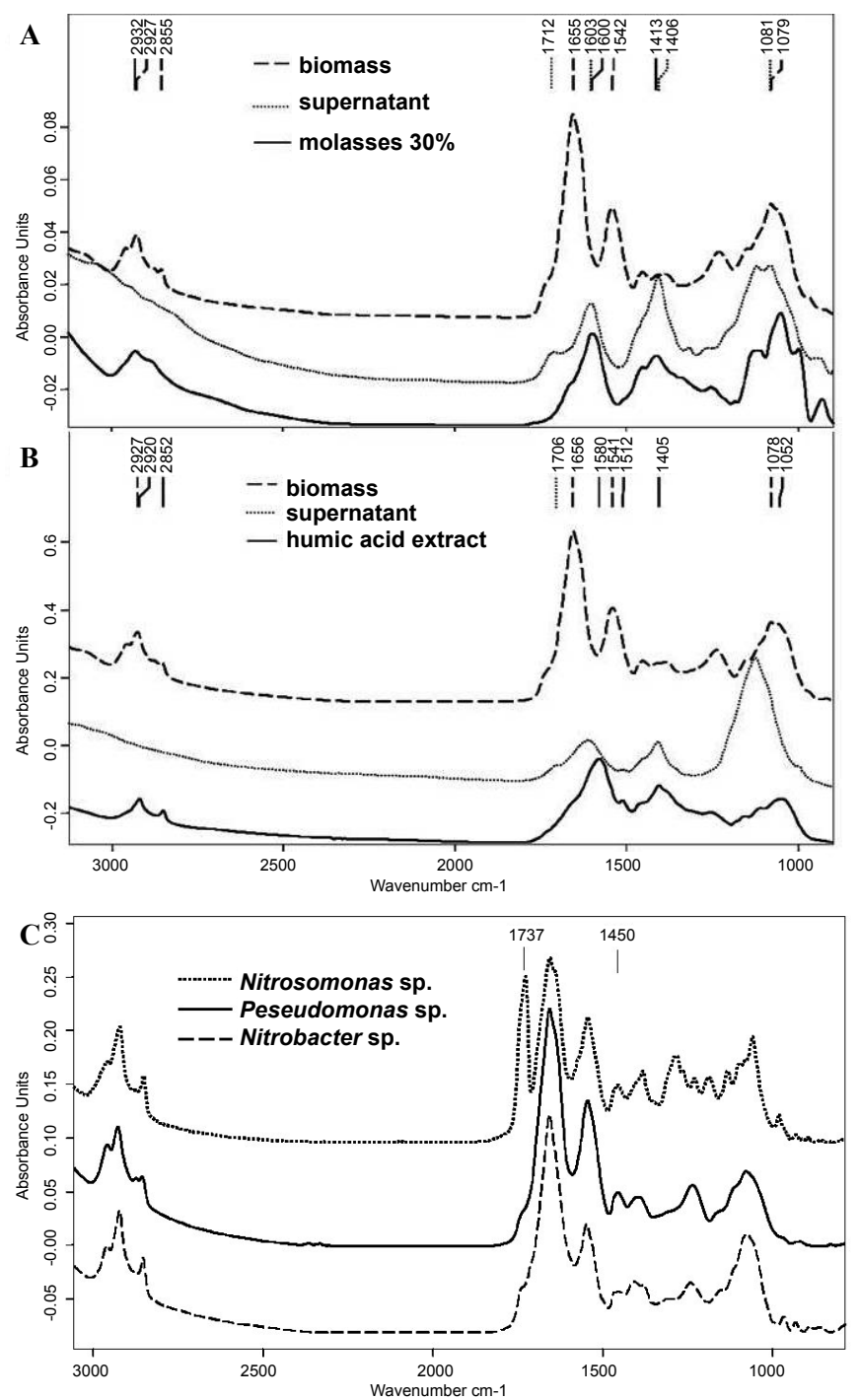

Figure 5: FT-IR spectra of different parts of the system: ceramic beads pretreated with molasses (A), humic acid extract (B), FT-IR spectra of individual PNN consortium strain biomass grown on TGA (C).

The addition of $0.45 \%$ fructose to the media enhanced the degradation of ammonium (Figure 6). The role of limited amounts of organic compounds, particularly fructose, as a carbon source to support the growth of Nitrosomonas spp. has been reported by Hommes et al. [30] and Schmidt [31]. The ability of Nitrobacter spp. to grow heterotrophically has also been documented previously $[29,32,33]$.

In the present experiments, maximum ammonium removal was detected after the first $24 \mathrm{~h}$. Further decrease in ammonium removal rate was limited by the amount of fructose left in media (Figure 7A). The highest consumption of fructose by the PNN consortium was detected in case of the pretreatment with molasses (Figure 7B). Moreover, molasses pretreatment provides the consortium with additional source of fructose. Analysis of the carbohydrates in the molasses revealed that $27 \%$ of the total reducing sugars were fructose (results not shown).

The decrease in ammonium removal from the system could be explained by the cyclic growth and detachment of the biofilm in a submerged biofilter. The ammonium removal cycle is affected by 


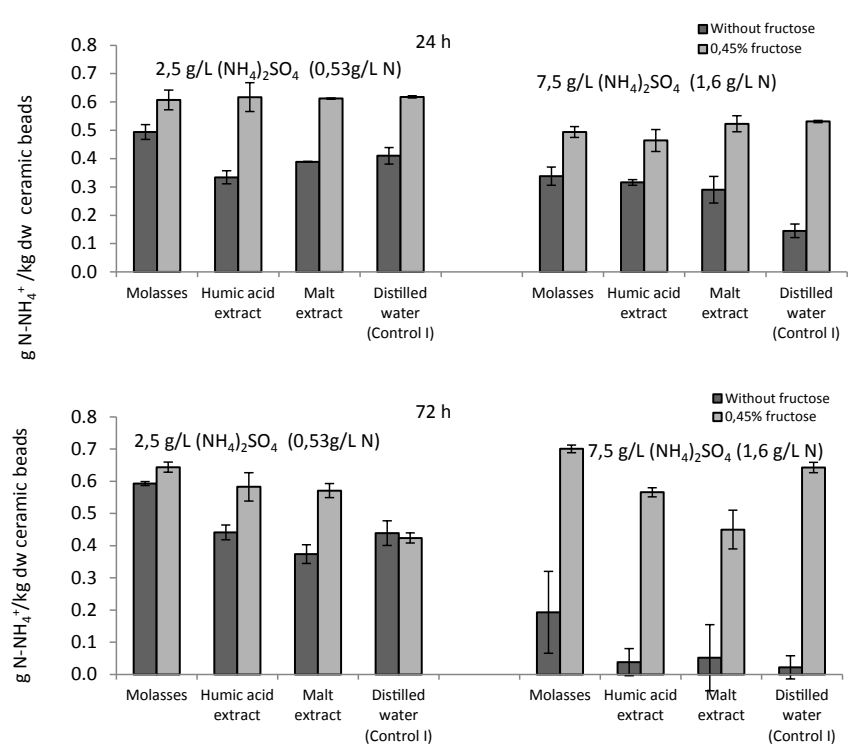

Figure 6: The impact of fructose, initial ammonium concentration, and the type of bead pretreatment on the ammonium nitrogen $\left(\mathrm{N}-\mathrm{NH}_{4}^{+}\right)$concentration in the liquid medium after incubation of the attached PNN consortium for $24 \mathrm{~h}$ and $72 \mathrm{~h}$. The initial concentrations of $\left(\mathrm{NH}_{4}\right) 2 \mathrm{SO}$ were $2.5 \mathrm{~g} / \mathrm{L}$ and $7.5 \mathrm{~g} / \mathrm{l}$, respectively. Error bars represent the standard deviation.
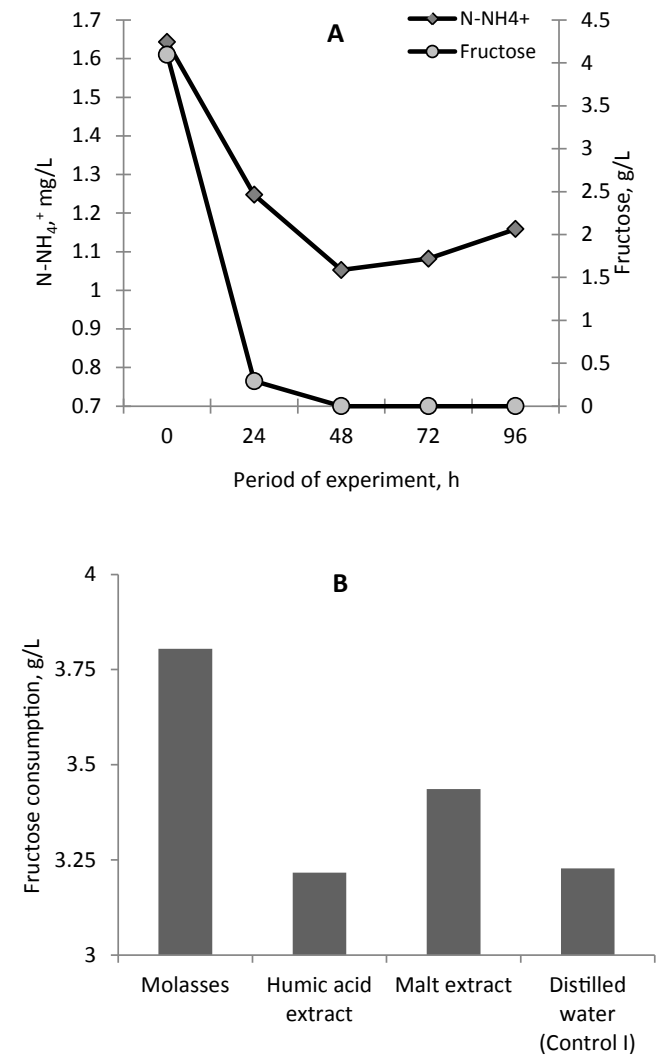

Figure 7: Ammonium degradation and fructose consumption by the attached PNN consortium during $96 \mathrm{~h}$ incubation in the liquid medium with $7.5 \mathrm{~g} / \mathrm{L}_{(}\left(\mathrm{NH}_{4}\right) 2 \mathrm{SO}_{4}$. (A) Concentration of fructose and ammonium over time (pretreatment of beads with molasses). (B) The effect of pretreatment type of ceramic beads on the fructose consumption. Beads treatment was performed as indicated in Materials and Methods. hydraulic conditions, temperature ranges, suspended solids, as well as ammonium concentration [34].

It is important to note that, in present experiments, the addition of fructose notably affected the $\mathrm{pH}$ level of the media. A $72 \mathrm{~h}$ incubation of the PNN consortium attached on the beads with different pretreatment types resulted in the decrease of $\mathrm{pH}$ from 7.37 in the sterile medium (control) to 5.4-5.6 and 6.8-7.1 in the sets with and without fructose, respectively. Redox potential increased from $-31.4 \mathrm{mV}$ in the sterile medium to $60.2-71.6 \mathrm{mV}$ and -17 to $-5 \mathrm{mV}$ with and without addition of fructose, respectively. Usually the medium for nitrifiers contains $\mathrm{CaCO}_{3}$ in order to maintain an elevated $\mathrm{pH}$ level. In the present study, $\mathrm{CaCO}_{3}$ was not added to the medium; therefore, the $\mathrm{pH}$ level was more variable and was dependent on the microbial activity. The optimal $\mathrm{pH}$ for the growth of nitrifying bacteria varies widely, typically from 7.0 to 9.0; the optimum $\mathrm{pH}$ range for Nitrosomonas spp. is 7.2 to 8.8 and for Nitrobacter spp. is 7.2 to 9.0 [35]. However, autotrophic nitrification at low $\mathrm{pH}$ is more widespread than previously thought. The ability of chemolithotrophic bacteria, in particular, Nitrosomonas spp., to nitrify at low $\mathrm{pH}$ was reported by Tarre and Green [36]. This study was attributed to biofilm and suspended-biomass reactors with $\mathrm{pH} 4.3$ and bulk ammonium concentration of $9.3 \mathrm{mg} / \mathrm{L}$ under autotrophic conditions [36].

\section{Conclusions}

Ceramic beads are an appropriate carrier for the immobilization of the PNN consortium in the submerged biofiltration system. Molasses pretreatment can significantly $(\mathrm{p}<0.05)$ stimulate the process of bacterial attachment on the ceramic carrier and the degradation of ammonium $(\mathrm{p}<0.05)$ in the submerged system, particularly in case of low initial concentrations of ammonium. The addition of $0.45 \%$ fructose to the media stimulated the degradation of ammonium. The results obtained in this laboratory-based study need to be further tested in a larger scale biofiltration system using waste water from a fish processing factory.

\section{Acknowledgments}

This study was financed by the State Research program Nr. 2010.10-4/VPP5 NatRes, subproject Y3-26493. Authors are grateful to Konnie Andrews for her suggested manuscript revisions.

\section{References}

1. Kennes C, Veiga MC (2002) Inert filter media for the biofiltration of waste gases - characteristics and biomass control. Rev Environ Sci Biotechnol 1: 201-214.

2. Lyssenko C, Wheaton $F$ (2006) Impact of positive ramp short-term operating disturbances on ammonia removal by trickling and submerged-upflow biofilters for intensive recirculating aquaculture. Aquacult Eng 35: 26-37.

3. Rene ER, Spackova R, Veiga MC, Kennes C (2010) Biofiltration of mixtures of gas-phase styrene and acetone with the fungus Sporothrix variecibatus. J Hazard Mater 184: 204-214.

4. García-Peña I, Ortiz I, Hernández S, Revah S (2008) Biofiltration of BTEX by the fungus Paecilomyces variotii. Int Biodeterior Biodegrad 62: 442-447.

5. Kumar VJ, Achuthan C, Manju NJ, Philip R, Singh IS (2009) Activated packed bed bioreactor for rapid nitrification in brackish water hatchery systems. J Ind Microbiol Biotechnol 36: 355-365.

6. Sakuma T, Hattori T, Deshusses MA (2006) Comparison of different packing materials for the biofiltration of air toxics. J Air Waste Manag Assoc 56: 1567 1575.

7. Kent TD, Fitzpatrick CSB, Williams SC (1996) Testing of biological aerated filter (BAF) media. Water Science and Technology 34: 363-370.

8. Han S, Yue Q, Yue M, Gao B, Zhao Y, et al. (2009) Effect of sludge-fly ash ceramic particles (SFCP) on synthetic wastewater treatment in an $A / O$ combined biological aerated filter. Bioresour Technol 100: 1149-1155. 
Citation: Muter O, Mihailova A, Berzins A, Shvirksts K, Patmalnieks A, et al. (2014) Optimization of Nitrification Process by a Bacterial Consortium in the Submerged Biofiltration System with Ceramic Bead Carrier. J Microb Biochem Technol 6: 148-153. doi:10.4172/1948-5948.1000136

9. Hirai M, Kamamoto M, Yani M, Shoda M (2001) Comparison of the biological $\mathrm{NH}_{3}$ removal characteristics among four inorganic packing materials. J Biosci Bioeng 91: 428-430.

10. Yun S-I, Ohta $Y(1998)$ Removal of gaseous n-valeric acid in the air by Rhodococcus sp. B261 immobilized onto ceramic beads. World J Microbiol Biotechnol 14: 343-348

11. Cho KS, Ryu HW, Lee NY (2000) Biological deodorization of hydrogen sulfide using porous lava as a carrier of Thiobacillus thiooxidans. J Biosci Bioeng 90: 25-31.

12. Kim S, Deshusses MA (2008) Determination of mass transfer coefficients for packing materials used in biofilters and biotrickling filters for air pollution control. 1. Experimental results. Chem Eng Sci 63: 841-855.

13. Ralebitso-Senior TK, Senior E, Di Felice R, Jarvis K (2012) Waste gas biofiltration: advances and limitations of current approaches in microbiology. Environ Sci Technol 46: 8542-8573.

14. Ortiz I, Revah S, Auria R (2003) Effects of packing material on the biofiltration of benzene, toluene and xylene vapours. Environ Technol 24: 265-275.

15. Guo J, Peng Y, Wang S, Ma B, Ge S, Wang Z, Huang H, Zhang J, Zhang L (2013) Pathways and organisms involved in ammonia oxidation and nitrous oxide emission. Crit Rev Environ Sci Technol 43: 2213-2296.

16. Raby K, Ramirez AA, Heitz M (2013) Elimination of nitrogen present in swine manure using a high-efficiency biotrickling filter. Environ Technol 34: 813-824.

17. Mihailova A, Muter O, Strikauska S, Limane B, Berzins U, et al. (2008) Comparison of the effect of various amendments on the growth of the targeted bacteria association and ammonia biodegradation, in Selected papers of the 7th International Conference "Environmental Engineering", edited by Cygas D, Froehner KD (Eds.), Vilnius 22-23 May, 2008, 218-223.

18. Treccani L, Yvonne Klein T, Meder F, Pardun K, Rezwan K (2013) Functionalized ceramics for biomedical, biotechnological and environmental applications. Acta Biomater 9: 7115-7150.

19. Hemmerly TE (1983) Traditional method of making sorghum molasses. Econ Bot 37: 406-409.

20. Hofrichter M, Steinbüchel A (2004) Biopolymers. Vol. 1. Lignin, humic substances and coal. Weinheim, NY: Wiley Europe-VCH.

21. Laitila A, Kotaviita E, Peltola P, Home S, Wilhelmson A (2007) Indigenous Microbial Community of Barley Greatly Influences Grain Germination and Malt Quality. J Inst Brew 113: 9-20.

22. Strikauska S, Zarina D, Berzins A, Viesturs U (1999) Biodegradation of ammonia by two stage biofiltration system. Environ Eng Policy 1: 175-179.
23. Chen W, Hoitink AJ, Schmitthenner AF, Tuovinen $\mathrm{OH}$ (1988) The role of microbial activity in suspension of damping-off caused by Pythium ultimum. Phytopathology 78: 314-322.

24. Grube M, Bekers M, Upite D, Kaminska E (2002) IR-spectroscopic studies of Zymomonas mobilis and levan precipitate. Vib Spectrosc 28: 277-285.

25. van den Akker B, Beard H, Kaeding U, Giglio S, Short MD (2010) Exploring the relationship between viscous bulking and ammonia-oxidiser abundance in activated sludge: A comparison of conventional and IFAS systems. Water Res 44: 2919-2929.

26. Reed DW, Smith JM, Francis CA, Fujita Y (2010) Responses of ammoniaoxidizing bacterial and archaeal populations to organic nitrogen amendments in low-nutrient groundwater. Appl Environ Microbiol 76: 2517-2523.

27. Petibois C, Wehbe K, Belbachir K, Noreen R, Deleris G (2009) Current trends in the development of FTIR imaging for quantitative analysis of biological samples. Acta Physica Polonica A 115: 507-512.

28. Kansiz M, Billman-Jacobe H, Mcnaughton D (2000) Quantitative determination of the biodegradable polymer poly(b-hydroxybutyrate) in a recombinan Escherichia coli strain by use of mid-infrared spectroscopy and multivariative statistics. Appl Environ Microbiol 66: 3415-3420

29. Franco-Rivera A, Paniagua-Michel J, Zamora-Castro J (2007) Characterization and performance of constructed nitrifying biofilms during nitrogen bioremediation of a wastewater effluent. J Ind Microbiol Biotechnol 34: 279-287.

30. Hommes NG, Sayavedra-Soto LA, Arp DJ (2003) Chemolithoorganotrophic growth of Nitrosomonas europaea on fructose. J Bacteriol 185: 6809-6814.

31. Schmidt I (2009) Chemoorganoheterotrophic growth of Nitrosomonas europaea and Nitrosomonas eutropha. Curr Microbiol 59: 130-138.

32. Burrell PC, Keller J, Blackall LL (1998) Microbiology of a nitrite-oxidizing bioreactor. Appl Environ Microbiol 64: 1878-1883.

33. Kindaichi T, Ito T, Okabe S (2004) Ecophysiological interactions between nitrifying bacteria and heterotrophic bacteria in autotrophic nitrifying biofilms as determined by microautoradiography-fluorescence in situ hybridization. Appl Environ Microbiol 70: 1641-1650.

34. Tseng K-F, Wu K-L (2004) The ammonia removal cycle for a submerged biofilter used in a recirculating eel culture system. Aquacult Eng 31: 17-30.

35. Chen S, Ling J, Blancheton J-P (2006) Nitrification kinetics of biofilm as affected by water quality factors. Aquacult Eng 34: 179-197.

36. Tarre S, Green M (2004) High-rate nitrification at low $\mathrm{pH}$ in suspended- and attached-biomass reactors. Appl Environ Microbiol 70: 6481-6487. 